\title{
PENENTUAN KADAR KALSIUM PADA WANITA MENOPAUSE
}

\author{
Kalma \\ Jurusan Analis Kesehatan Poltekkes Kemenkes Makassar
}

Koresponden : kalmaanalis@gmail.com

\begin{abstract}
ABSTRAK
Menopause merupakan peristiwa alamiah dan normal terjadi pada seorang wanita, tetapi banyak menimbulkan keluhan dan gangguan yang dirasakan oleh wanita atau justru disangka sebagai gejala dari penyakit tertentu. Penurunan hormon estrogen yang terlibat dalam kehidupan wanita, terutama disebabkan oleh kehilangan fungsi ovarium yang semakin meningkat dengan bertambahnya usia wanita. Disamping itu penyerapan kalsium usus menurun bila usia bertambah. Terkait dengan itu perlu dteliti kadar kalsium wanita menopause. Sampel dalam penelitian ini adalah wanita menopause yang memenuhi kriteria sampel penelitian : wanita yang berusia berkisar 45-65 tahun, tidak mengalami menstruasi salama 12 bulan berturut-turut dan bersedia berpartisipasi dalam penelitian ini. Penelitian dilaksanakan di Laboratorium Jurusan Analis Kesehatan Politeknik Kesehatan Kementerian Kesehatan Makassar pada tanggal 07 sampai 11 Agustus 2017. Kadar kalsium ditentukan dengan metode Cresolphthalein-complex (CPC), dengan prinsip: ion kalsim bereaksi dengan 0-cresolphthalein-complexone dalam media basa untuk membentuk kompleks warna ungu. Absorbans kompleks yang terbentuk sebanding dengan konsentrasi kalsium dalam spesimen. Berdasarkan penelitian yang telah dilakukan dapat disimpulkan bahwa dari 20 sampel, 18 (90\%) wanita menopause kadar kalsium darahnya kurang dari normal. Untuk itu disarankan memenuhi asupan kalsium harian yang dibutuhkan tubuh pada masa menopause untuk mencegah terjadinya osteoporosis yang disebabkan oleh kekurangan kalsium.
\end{abstract}

Kata kunci: Kadar, Kalsium, Menopause, Wanita.

\section{PENDAHULUAN}

Menopause merupakan peristiwa yang sangat alamiah dan normal terjadi pada seorang wanita, tetapi banyak menimbulkan keluhan dan gangguan yang dirasakan oleh para wanita yang mengalami menopause biasanya hanya ditanggapi sebagai proses "menua" atau justru disangka sebagai gejala dari penyakit lain (Purwoastuti E, 2008).

Menopause adalah berhentinya haid secara alamiah yang biasanya terjadi pada usia 45-50 tahun atau masa berhentinya haid sama sekali salama 12 bulan berturut-turut. Menopause adalah penghentian permanen menstruasi (haid), berarti pula akhir dari masa reproduktif. Perubahan endokrin - hormon yang terlibat selama bertahun-tahun dalam kehidupan wanita ini,- terutama disebabkan oleh kehilangan fungsi ovarium yang semakin meningkat (Purwoastuti E, 2008).

Kalsium adalah mineral paling banyak dalam tubuh termasuk paling penting. Tubuh membutuhkan 
kalsium untuk membentuk dan menperbaiki tulang dan gigi, membantu fungsi saraf, kontraksi otot, pembentukan darah dan berperan pada fungsi jantung (Hardjoeno H, 2007).

Kalsium mempunyai peran yang penting dalam tubuh, yaitu dalam pembentukan tulang dan gigi, dalam pengaturan fungsi sel pada cairan ekstraseluler dan intraseluler, seperti untuk transmisi saraf, kontraksi otot, penggumpalan darah, dan menjaga perbeabilitas sel. Selain itu, kalsium juga mengatur pekerjaan hormon-hormon dan faktor pertumbuhan (Almatsier, 2002 dalam Arisman, 2004).

Kebanyakan penelitian menunjukkan bahwa penyerapan kalsium usus menurun bila usia bertambah. Selain itu, dengan bertambahnya usia, jumlah kalsium dari makanan yang kita butuhkan untuk mempertahankan keseimbangan kalsium tubuh akan meningkat. Turunnya kadar vitamin D aktif, yang kemungkinan disebabkan oleh turunnya produksi vitamin D karena penuaan atau kekurangan estrogen, dapat menyebabkan berkurangnya penyerapan kalsium usus. Selain itu, usus menua menjadi kebal terhadap aksi vitamin $\mathrm{D}$, dan ini mengakibatkan penyerapan kalsium berkurang (Lane N, 2003).

Berapa pun jumlah kalsium yang dikomsumsi dari makanan maupun dari suplemen, jika berada pada periode menopause, kalsium yang diserap lebih sedikit. Dengan demikian wanita membutuhkan lebih banyak kalsium setelah menopause dari pada sebelumnya (Lane N, 2003).
Ginjal bekerja untuk menyaring darah sebanyak kurang lebih 200 liter setiap harinya dan juga membuang sisa-sisa metabolism serta kelebihan cairan tubuh melalui urin. Selain membuang sisa-sisa metaboliseme, salah satu fungsi ginjal yaitu mengatur metabolisme ion kalsium dan vitamin D. fungsi ginjal dapat dipengaruhi oleh beberapa faktor salah satunya yaitu faktor usia, seiring bertambahnya usia juga akan diikuti penurunan fungsi ginjal. Hal tersebut terutama terjadi karena pada usia lebih dari 40 tahun akan terjadi proses hilangnya beberapa nefron. Nefron adalah unit fungsional terkecil dari ginjal yang terdiri atas glomeruli dan tubuli ginjal. Darah yang membawa sisa-sisa metabolisme tubuh difiltrasi (disaring) di dalam glomeruli kemudian di tubuli ginjal, beberapa zat yang masih diperlukan tubuh mengalami reabsorbsi dan zat-zat sisa metabolisme tubuh di sekresikan bersama air dalam bentuk urin (Asis F, 2008).

Dari latar belakang diatas maka rumusan masalah penelitian ini adalah bagaimana gambaran kadar kalsium pada wanita menopause?.

\section{METODE}

Jenis penelitian ini adalah penelitian observasional laboratorium dengan menggunakan metode pendekatan dekskriptif untuk mengetahui kadar kalsium pada wanita menopause.

Sampel dalam penelitian ini adalah wanita menopause yang memenuhi kriteria sampel penelitian: Wanita yang berusia berkisar 45-65 tahun, tidak mengalami menstruasi salama 12 bulan berturut-turut dan 
bersedia berpartisipasi dalam penelitian ini.

Instrumen Penelitian yaitu Spoit, kapas alcohol, kapas kering, turniket (tali pembendung), plester, tabung serologi, rak tabung, mikropipet dan tip, sentrifuge, tabung sentrifuge, pipet tetes dan Humalyzer 2000. Sedangkan bahan penelitian : Serum, reagen kerja (BUF+RGT), standar.

Prosedur penelitian

Pemeriksaan kadar kalsium

Metode: Cresolphthalein-complex (CPC)

Prinsip : Ion kalsim bereaksi dengan 0-cresolphthalein-complexone dalam media basa untuk membentuk kompleks warna ungu. Absorbans kompleks yang terbentuk sebanding dengan konsentrasi kalsium dalam sampel.

Pra analitik

Menyiapkan alat dan bahan

Pengambilan darah vena

Memilih salah satu vena, biasanya pada orang dewasa dipakai adalah fossa cubiti, desinfeksi dengan alcohol $70 \%$ dan biarkan sampai menjadi kering lagi, memasang tali pempendung atau turniket pada lengan atas dan meminta pasien mengepal dan membuka tangannya berkali-kali agar vena jelas terlihat. Pembendungan vena tidak perlu dengan ikatan erat-erat, bahkan sebaiknya hanya cukup erat untuk memperlihatkan dan agak menonjolkan vena, menegangkan kulit di atas vena itu dengan jari-jari tangan kiri supaya vena tidak dapat bergerak, menusuk kulit dengan jarum dan senprit dalam tangan kanan sampai urung jarum masuk kedalam lumen vena, melepaskan atau merenggangkan pembendungan dan perlahan-lahanlah menarik pengisap semprit sampai jumlah darah yang dikehendaki didapat, melepaskan pembendungan, menaruh kapas diatas jarum dan mencabut spot, meminta pasien untuk menekan bekas tusukan dengan kapas tadi, mengangkat jarum dari semprit dan mengalirkan (jangan semprot) darah ke dalam tabung eveluasi melalui dinding.

Persiapan sampel

sampel dalam tabung didiamkan sampai darah membeku kemudian disentrufuge selama 10 menit dengan kecepatan 1000 rpm, memisahkan antara komponen plasma dan komponen sel-sel darah. Komponen plasma disimpan pada tabung reaksi. Persiapan reagen

Untuk reagen kerja yaitu mencampurkan RGT dengan BUF dalam volume yang sama banyak (1 : 1) sesuai yang diperlukan.

Analitik

Cara kerja

Disiapkan alat dan bahan yang akan diguanakan, masing-masing tabung diberi label blanko, sandar, dan sampel. mengisi tabung blanko, standar dan sampel dengan reagen kerja masing-masing sebanyak 1000 $\mu 1$, mengisi tabung Standar dengan larutan STD sebanyak $20 \mu$ l, mengisi tabung Sampel dengan sampel sebanyak $20 \mu$ l, kemudian didiamkan pada suku kamar selama 5-30 menit, dibaca absorbance dengan menggunakan Humalyzer 2000.

Cara penggunaan alat Humalyzer 2000

Pastikan alat sudah siap digunakan, pilih MENU, kemudian tekan nomor (sesuai parameter pemeriksaan) lalu ENTER, apabila menggunakan blanko yang disiapkan sendiri tekan NO kemudian tekan NO, bila perintah 
READ BLANK muncul, dimasukkan pipet Humalyzer hingga ke dasar tabung reaksi, lalu tekan tombol untuk menghisap agar Blanko dapat dibaca oleh alat, untuk membaca Standar dan Sampel maka lakukan hal yang sama seperti saat akan membaca Blanko, tekan CLEAR sebanyak 2 kali , print hasil pembacaan, untuk membersihkan, masukkan pipet Humalyzer dalam wadah berisi air lalu tekan PURGE, hingga larutan yang dibuang tidak lagi berwarna.

Pasca analitik. Mencatat hasil penelitian. Hasil penelitian disajikan

Tabel 1.

Hasil Penentuan Kadar Kalsium Darah Wanita Menopause

\begin{tabular}{ccc}
\hline No & Kode sampel & Kadar kalsium \\
\hline 1 & $\mathrm{~A}$ & $7,6 \mathrm{mg} / \mathrm{dl}$ \\
2 & $\mathrm{~B}$ & $7,5 \mathrm{mg} / \mathrm{dl}$ \\
3 & $\mathrm{C}$ & $8,1 \mathrm{mg} / \mathrm{dl}$ \\
4 & $\mathrm{D}$ & $7,9 \mathrm{mg} / \mathrm{dl}$ \\
5 & $\mathrm{E}$ & $6,7 \mathrm{mg} / \mathrm{dl}$ \\
6 & $\mathrm{~F}$ & $7,3 \mathrm{mg} / \mathrm{dl}$ \\
7 & $\mathrm{G}$ & $7,4 \mathrm{mg} / \mathrm{dl}$ \\
8 & $\mathrm{H}$ & $6,9 \mathrm{mg} / \mathrm{dl}$ \\
9 & $\mathrm{I}$ & $7,2 \mathrm{mg} / \mathrm{dl}$ \\
10 & $\mathrm{~J}$ & $7,9 \mathrm{mg} / \mathrm{dl}$ \\
11 & $\mathrm{~K}$ & $7,6 \mathrm{mg} / \mathrm{dl}$ \\
12 & $\mathrm{~L}$ & $7,5 \mathrm{mg} / \mathrm{dl}$ \\
13 & $\mathrm{M}$ & $8,0 \mathrm{mg} / \mathrm{dl}$ \\
14 & $\mathrm{~N}$ & $7,1 \mathrm{mg} / \mathrm{dl}$ \\
15 & $\mathrm{O}$ & $7,5 \mathrm{mg} / \mathrm{dl}$ \\
16 & $\mathrm{P}$ & $7,5 \mathrm{mg} / \mathrm{dl}$ \\
17 & $\mathrm{Q}$ & $8,1 \mathrm{mg} / \mathrm{dl}$ \\
18 & $\mathrm{R}$ & $7,9 \mathrm{mg} / \mathrm{dl}$ \\
19 & $\mathrm{~S}$ & $7,7 \mathrm{mg} / \mathrm{dl}$ \\
20 & $\mathrm{~T}$ & $7,3 \mathrm{mg} / \mathrm{dl}$ \\
\hline
\end{tabular}

Sumber : Data Primer, 2017

\section{PEMBAHASAN}

Hasil pemeriksaan pada tabel menunjukkan bahwa kadar kalsium darah pada wanita menopause normal sebanyak 2 orang (10\%), kurang dari normal sebanyak 18 orang $(90 \%)$. dalam bentuk tabel kemudian dianalisa secara deskriptif

\section{HASIL}

Berdasarkan hasil penentuan kadar kalsium darah pada wanita menopause sebanyak 20 orang, diperoleh data seperti tabel berikut.

Pada penelitian ini diambil sampel darah vena untuk pemeriksaan kadar kalsium pada wanita menopause dengan terlabih dahulu melalukan kuesioner berdasarkan kriteria sampel. 
Pemeriksaan kadar kalsium megguanakan fotometrik dengan metode CPC (cresolphteleincomplex) dengan prinsip ion kalsium bereaksi dengan o-cresolphtelein complexone dalam media alkali sehingga membentuk kompleks warna ungu. Absorbance kompleks yang terbentuk sebanding dengan konsentrasi kalsium dalam sampel. Alat yang digunakan yaitu Humalyzer 2000.

Berdasarkan hasil pemeriksaan dapat dilihat sebagian besar sampel $18(90 \%)$ dari 20 sampel mengalami penurunan kadar kalsium dan hanya 2 (10\%) sampel berada pada ambang batas normal. Hal ini dapat disebabkan antara lain karena kurangnya asupan kalsium yang berasal dari makanan dan atau kurangnya hormon estrogen pada saat menpause. Kondisi seperti ini berpotensi menyebabkan terjadinya osteoporosis.

Pada saat menopause terjadi penurunan hormon estrogen yang menyebabkan penurunan penyerapan kalsium oleh usus. Sedangkan kadar kalsium yang normal adalah $10 \%$, karena keburuhan kalsium harian yang terpenuhi. Tetapi semua berada pada ambang batas yang paling bawah karena pada dasarnya pada masa menopause tubuh membutuhkan lebih banyak asupan kalsium.

Berapapun jumlah kalsium yang dikonsumsi dari makanan maupun dari suplemen, jika berada pada periode menopause, kalsium yang diserap lebih sedikit. Dengan demikian wanita membutuhkan lebih banyak kalsium setelah menopause dari pada sebelumnya (Lane N, 2003)
Penyerapan kalsium usus menurun bila usia bertambah. Selain itu, dengan bertambahnya usia, jumlah kalsium dari makanan yang kita butuhkan untuk mempertahan keseimbangan kalsium tubuh akan meningkat. Turunya kadar vitamin D aktif, yang kemungkinan disebabkan oleh turunnya produksi vitamin D karena penuaan atau kekurangan estrogen, dapat menyebabkan berkurangnya penyerapan kalsium usus. Selain itu, usus menua menjadi kebal terhadap aksi vitamin $\mathrm{D}$, dan ini mengakibatkan penyerapan kalsium berkurang (Lane N, 2003).

Ginjal bekerja untuk menyaring darah sebanyak kurang lebih 200 liter setiap harinya dan juga membuang sisa-sisa metabolisme serta kelebihan cairan tubuh melalui urin. Selain membuang sisa-sisa metaboliseme, salah satu fungsi ginjal yaitu mengatur metabolisme ion kalsium dan vitamin D. fungsi ginjal dapat dipengaruhi oleh beberapa faktor salah satunya yaitu faktor usia, seiring bertambahnya usia juga akan diikuti penurunan fungsi ginjal. Hal tersebut terutama terjadi karena pada usia lebih dari 40 tahun akan terjadi proses hilangnya beberapa nefron. Nefron adalah unit fungsional terkecil dari ginjal yang terdiri atas glomeruli dan tubuli ginjal. Darah yang membawa sisa-sisa metabolism tubuh difiltrasi (disaring) di dalam glomeruli kemudian di tubuli ginjal, beberapa zat yang masih diperlukan tubuh mengalami reabsorbsi dan zatzat sisa metabolism tubuh di sekresikan bersama air dalam bentuk urin (Asis F.M, 2008).

Gaya hidup yang sehat akan membantu wanita dalam beradaptasi terhadap perubahan-perubahan yang 
timbul saat menopause. Misalnya penerapan pola makan yang sehat terhadap sejumlah nutrisi yang sangat penting saat wanita mengalami menopause antara lain Protein

Protein merupakan gizi yang paling penting, karena tanpa protein manusia tidak mungkin hidup. Protein berguna untuk pertumbuhan, perbaikan sel-sel tubuh, dan produksi enzim serta hormon.

Kalsium merupakan komponen tulang dan gigi. Kekurangan kalsium dan komponen lainnya dalam tubuh menyebabka osteoporosis.

Kalsium merupakan mineral yang paling banyak terdapat dalam tubuh, sekitar 99\% total kalsium dalam tubuh ditemukan dalam jaringan keras yaitu tulang dan gigi, hanya sebagian kecil dalam plasma cairan ekstravaskuler.

Kalsium tulang berada pada keadaan seimbang dengan kalsium plasma pada konsentrasi sekitar 2,252,60 $\mathrm{mmol} / \mathrm{L}(9-10,4 \mathrm{mg} / 100 \mathrm{ml})$. Jumlah kalsium dalam tulang berubah menurut umur, ukuran, dan komposisi tubuh dan akan mengalami penurunan masa tulang sejalan dengan pertambahan umur (Almatsier, 2006 dalam Arisman, 2004).

Kalsium mempunyai peran yang penting dalam tubuh, yaitu dalam pembentukan tulang dan gigi, dalam pengaturan fungsi sel pada cairan ekstraseluler dan intraseluler, seperti untuk transmisi saraf, kontraksi otot, penggumpalan darah, dan menjaga perbeabilitas sel. Selain itu, kalsium juga mengatur pekerjaan hormon-hormon dan faktor pertumbuhan.

Kalsium tidak hanya penting bagi tulang yang sehat tapi juga bagi setiap sistem dan proses dalam tubuh. Karena kalsium sangat penting, tubuh telah mengembangkan sistem hormon yang luas menjaga tingkat hormon tetap konstan dalam darah. Unsurunsur yang penting adalah hormon parathyroid, vitamin $\mathrm{D}$, dan kalsitonin.

Hormon parathyroid dibuat didalam empat kelenjar kecil parathyroid yang terselip dibelakang leher dan berhubungan dengan kelenjar thyroid. Hormon parathyroid mengontrol tingkat kalsium dalam darah. Jika tingkat ini turun di bawah poin tertentu, hormon ini dilepaskan dari aliran darah dan meningkatkan tingkat kalsium dalam darah dengan beberapa cara. Karena kalsium penting bagi kesehatan otak dan sel, masa tulang mungkin berkorban untuk memastikan tingkat kalsium yang memadai dalam aliran darah.

Vitamin D didapat terutama dari matahari, di mana vitamin ini diproduksi oleh sinar ultraviolet pada bentuk tidak aktif dari vitamin ini pada kulit. Vitamin ini juga ditemukan dalam jumlah kecil pada telur, susu, dan ikan. Vitamin D disimpan di hati dalam bentuk yang diaktifkan sebagian dan disalurkan ke ginjal, di mana vitamin ini diubah menjadi bentuk aktif. Setelah diaktifkan, vitsmin D meningkatkan penyerapan kalsium dari usus dan merangsang ginjal untuk menyerap kembali kalsium dari urin kembali ke aliran darah. Vitamin D seperti halnya hormon parathyroid, bertanggung jawab untuk mempertahankan tingkat kelsium tertentu dalam darah. Jadi, jumlah vitamin D yang benar penting dalam mempertahankan keseimbangan kalsium. 
Hormon lainnya, kalsitonin, dibuat dalam kelenjer thyroid. Hormon ini melindungi tulang dari efek resorption yang disebabkan oleh hormon parathyroid (Lane N, 2003).

Kurangnya asupan kalsium dapat berakibat buruk terhadap tubuh. Akibat defisiensi kalsium antara lain : Osteoporosis

Menurut World Health Organization (WHO) pada tahun 1994, mendefinisikan osteoporosis sebagai suatu penyakit tulang sistemik dengan karakteristik yang khas yaitu rendahnya massa tulang $\mathrm{d}$ dan mundurnya kualitas jaringan pada tulang.

Osteoporosis disebabkan oleh menurunnya massa tulang akibat absorpsi kalsium yang kurang baik, kurangnya jumlah kalsium dalam makanan yang berlansung lama, proses resorpsi tulang (keluarnya kalsium dari tulang) yang meningkat dan proses kalsifikasi (masuknya kalsium kedalam matriks tulang), tulang yang terhambat.

Osteomalasia

Osteomalasia ialah kondisi penurunan kualitas tulang. Keadaan ini sering ditemukan pada wanita yang tinggal didaerah subtropics dimana intensitas sinar matahari rendah dan jarang keluar rumah (jarang terkena sinar matahari), atau kekurang cadangan mineral kalsium.

Kanker kolon

Beberapa studi menunjukan korelasi terbalik antara kejadian asupan kalsium dengan kejadian kanker kolon, meningkatkan asupan kalsium mampu mengurangi resiko terkena kanker kolon yaitu dengan mengurangi konsentrasi asam empedu bebas fekel dan asam lemak bebas, sehingga mengurangi sitotoksisitas.

Tetani

Kadar kalsium darah yang sangat rendah dapat menyebabkan tetani atau kejang. Kepekaan serabut saraf dan pusat saraf terhadap rangsangan meningkat, sehingga terjadi kejang otot misalnya pada kaki (Almatsier, 2006 dalam Arisman, 2004).

\section{KESIMPULAN}

Berdasarkan penelitian yang telah dilakukan dapat disimpulkan bahwa dari 20 sampel, 18 (90\%) wanita menopause kadar kalsium darahnya kurang dari normal.

\section{SARAN}

Perlu memenuhi asupan kalsium harian yang dibutuhkan tubuh pada masa menopause untuk mencegah terjadinya osteoporosis yang disebabkan oleh kekurangan kalsium.

\section{DAFTAR PUSTAKA}

Arisman. 2004. Gizi Dalam Daur Kehidupan. Jakarta:Buku Kedokteran EGC

Asis Farid, M. 2008. Panduan Pelayanan Medik Model Interdisiplin

Penetalaksanaan. Jakarta: EGC

Hardjoeno, H. 2007. Subtansi dan Cairan Tubuh. Makassar: Lembaga Penerbit Universitas Hasanuddin.

Lane, Nancy. 2003. Osteoporosis Rapuh Tulang Edisi 1 Cetakan 2. Jakarta: PT Raja Grafindo Persada.

Pilliang, Wiranda G \& Djojosoebagio Al-Haj, Soewondo. 2006. 
Jurnal Media Analis Kesehatan, Vol. 8, No.2, November 2017 http://journal.poltekkes-mks.ac.id/ojs2/index.php/mediaanalis e-ISSN : 2621-9557 p-ISSN : 2087-1333

Fisiologi Nutrisi Volume II. Bogor: IPB Press.

Purwoastuti, Endang. 2008. Menopause, Siapa Takut?. Yokyakarta: Kaniasus. 